$\mathrm{Oz}$

$1-1-1994$

\title{
Wild Walls: Domus Linea Insecare as Dreamt by Scogin Elam and Gray Architects
}

D. S. Friedman

Follow this and additional works at: https://newprairiepress.org/oz

(c) (i) $\Theta \Theta$

This work is licensed under a Creative Commons Attribution-Noncommercial-No Derivative Works 4.0 License.

\section{Recommended Citation}

Friedman, D. S. (1994) "Wild Walls: Domus Linea Insecare as Dreamt by Scogin Elam and Gray Architects," Oz: Vol. 16. https://doi.org/10.4148/2378-5853.1258

This Article is brought to you for free and open access by New Prairie Press. It has been accepted for inclusion in Oz by an authorized administrator of New Prairie Press. For more information, please contact cads@k-state.edu. 


\section{Wild Walls}

Domus Linea Insecare (The House Above the Bug-Line)

as Dreamt by Scogin Elam and Bray Architects

\section{D.S. Friedman}

Architects have given particular shape to our understanding of the house, especial$l y$ in modern times. "The Architect's Dream," a recent exhibition at The Contemporary Arts Center in Cincinnati, set out to discover how architects foresee change in the form and institution of domestic space at the close of the twentieth century. The exhibition curators invited thirty architects and architecture firms representing a broad range of talents and perspectives to submit portfolios for review as potential exhibitors. From this group, the curators commissioned sixteen architects-some working alone, some in partnerships, and some in teams-to design eleven projects.

The following essay, reprinted here with the permission of The Contemporary Arts Center, is adapted from the introduction to the exhibit catalogue.

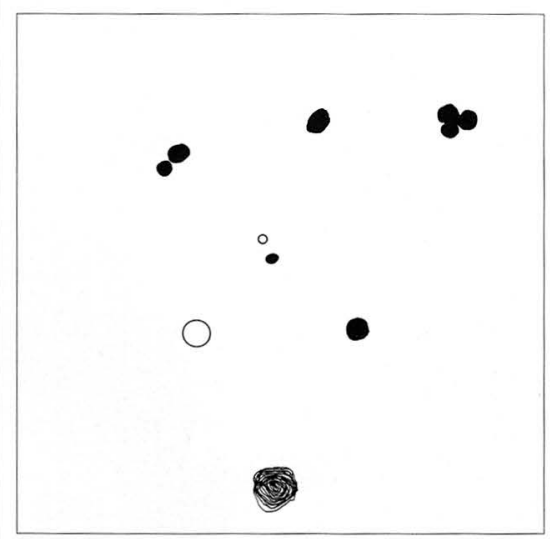

Everybody, quite rightly, dreams of sheltering himself in a sure and permanent home of his own. This dream, because it is impossible in the state of things, is deemed incapable of realization and so provokes an actual state of sentimental hysteria; to build one's own house is very much like making one's will..

\section{—Le Corbusier}

This house, beyond all water, wind, cold, fog, light, and darkness, and once also beyond all noise, shelters-just as the belly ship separates us from the coldness of the ocean. It is a second skin which enlarges our sensorium. It is a casing, then sight, an eye.

\section{-Michael Serres}

$A$ house is only a house inasmuch as it is haunted.

—Mark Wigley

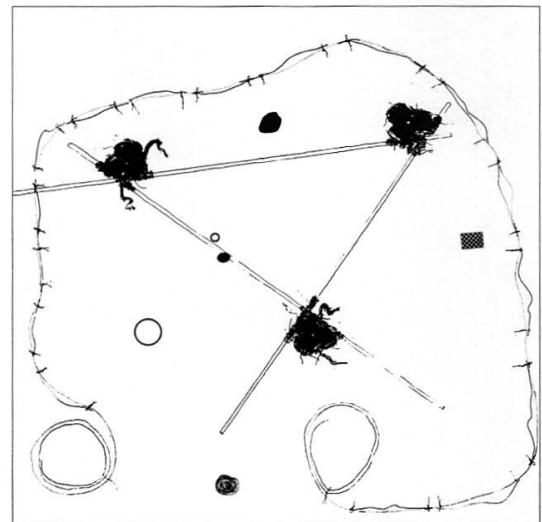

Plan 1
Like the other projects in The Architect's Dream exhibition, Scogin Elam Bray's Domus Linea Insecare represents a critical practice: it puts the commonplace dream-house into abeyance; it develops dream house as a topic, not an object; it exercises this topic in respect to the changing status of domestic experience; it carries the spatial and material experience of architecture into its inhabitant it questions architectural thinking as a measure of the changing constitution of the postmodern subject (the self, the 'I'); it examines the way the subject of the house reflects the question of being and embodiment.

First walls, whether skin or stone, always implicate the flesh of the world. The exterior and interior of the 'house' correspond to the exterior and interior of the 'body'. When the fifteenth century architect Leon Battista Alberti writes that "the city is like some large house and the house is in turn like some small city," he

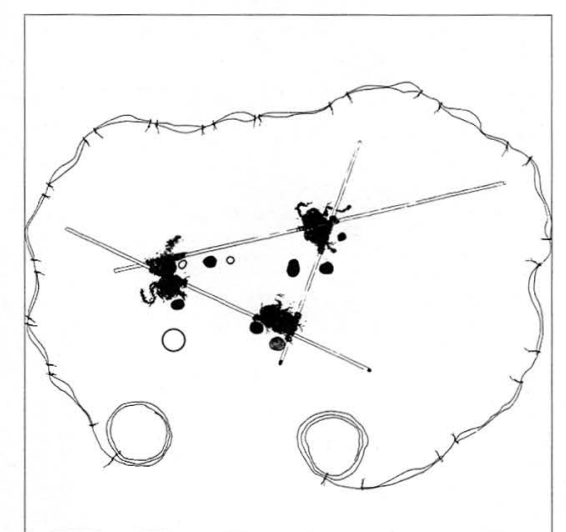

Plan 2 extends the characteristics of domestic value across the whole fabric of urban life. The Albertian house yields the ideal city; it exemplifies corporeal and gestural dignity. Alberti wants it to serve as a platform for productive political relations, for a healthy body politic. In his view, ornament and rhetoric are not superfluous additions to this fabric, they are essential, constitutive ingredients. We find Alberti at the head of a long line of Renaissance trattatisti who believe that classical principles, activated by chaosdispelling geometry, embody a larger, harmonious, unifying cosmic order. Architectural theory has sustained this anthropomorphism for over two millennia, through the organicism of Frank Lloyd Wright and the Modulor of Le Corbusier, and through Louis I. Kahn's talking bricks.

In the late twentieth century, however, the white, male body and its projects are no longer the measure of all things. Con-

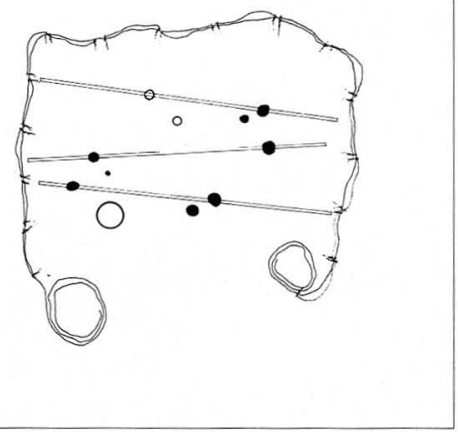

Plan 3 
air
dream house

basket house

air house

tree house / pole house

screen porch house

light house

open house

private house

star house

full body mask / model and house

lideody mask /

slide open house

e-up / slide-down house movable / mobile / fuxed

fold-down house

swing-out house

dom-ino unit / Rietveld house / Miesian clearness

a long telescoping stair

a lift

rain site / storm view

star view

tree view

rain sound

breeze

bug sound

grass sound

worm sound

earth

the house occupies poles anywhere they are abandoned (a post-technological condi tion) and becomes an "air squatter" above the bug line (mythological)...head in the tion) and becomes an "air squatter" above the bug line (mythological)...
clouds/wind/rain...catch the wind/catch the rain/ride the air/sleep star...

lifting

enter the green

swing together / apart one - two buckle my shoe

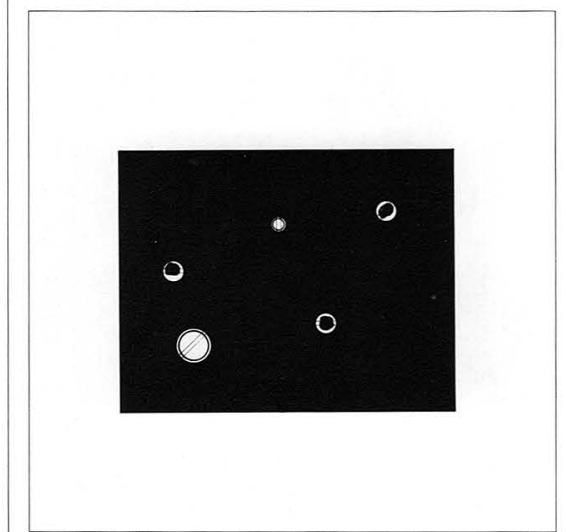

Plan 4

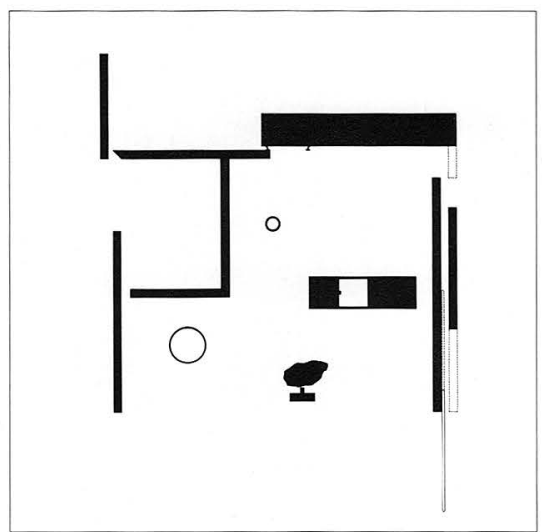

Plan 5

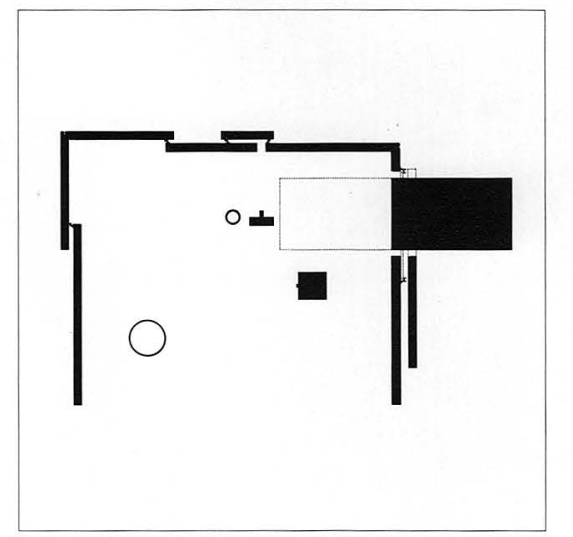

Plan 6

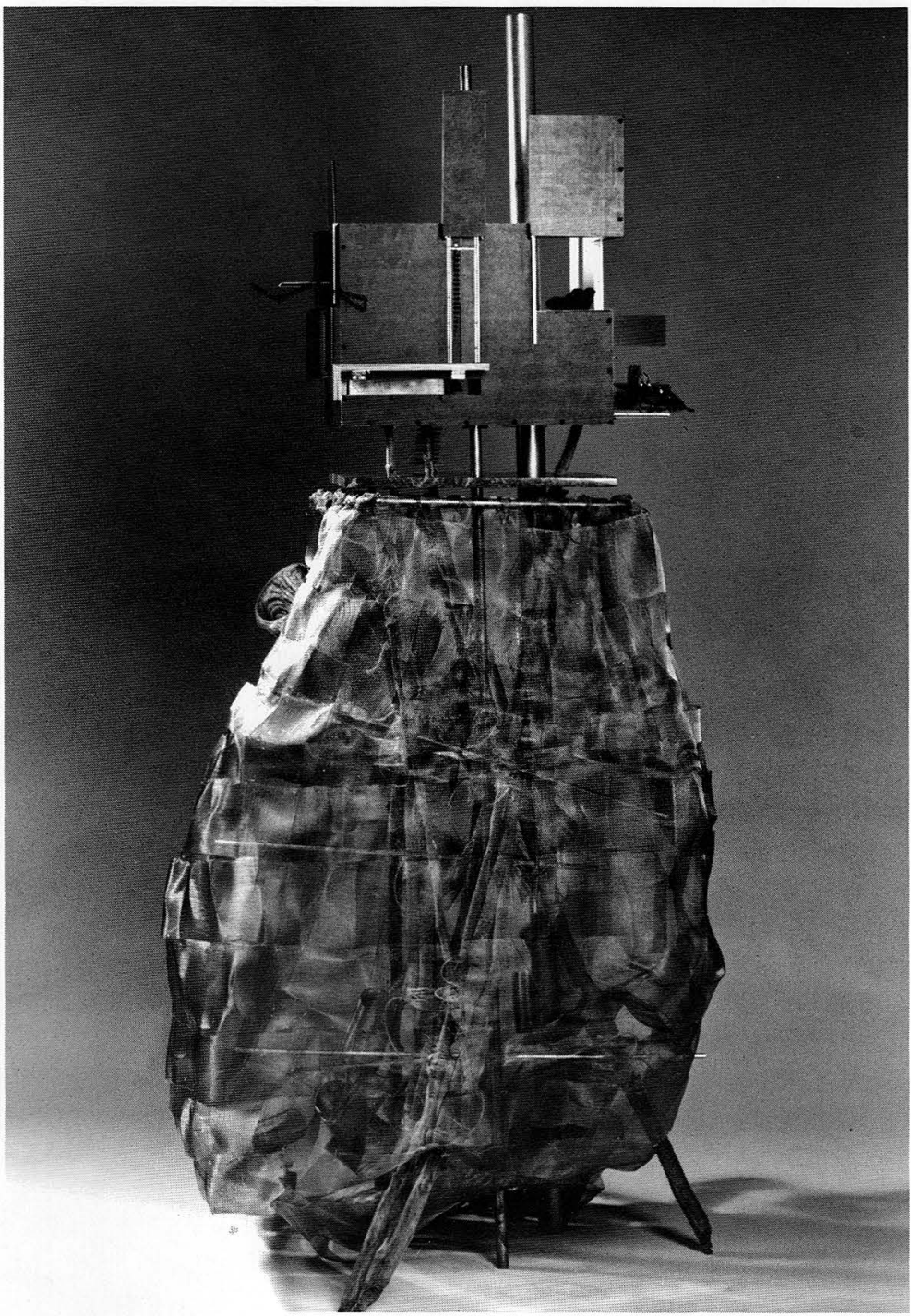

Domus Linea Insecare (a.k.a. House Above the Bug-Line)—photo: Ron Forth

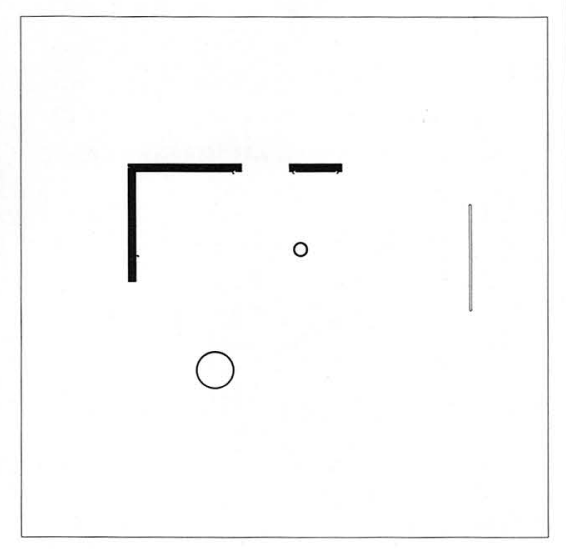

Plan 7 


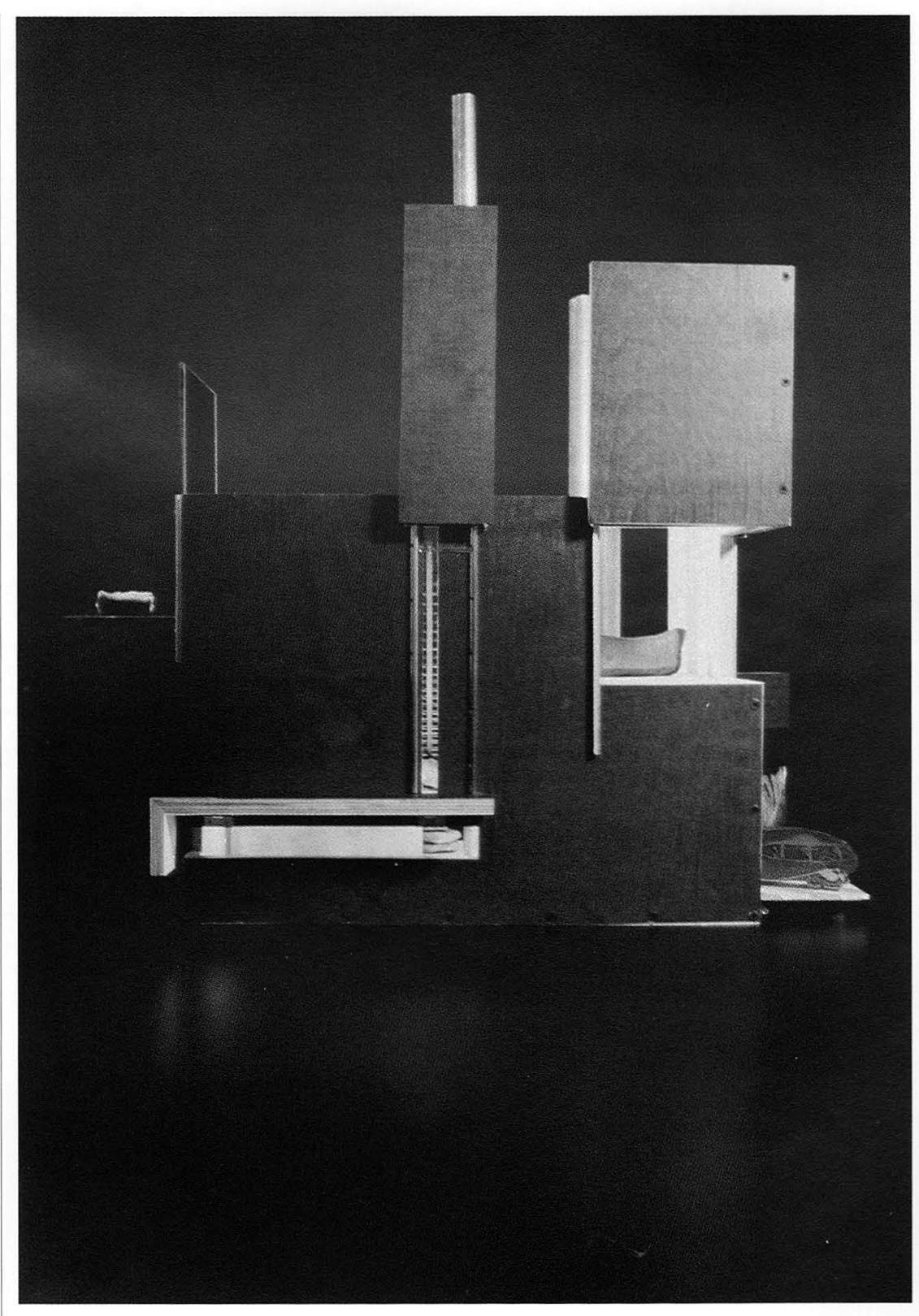

Domus Linea Insecare outside

temporary thinkers have dismantled the neoclassical and orthodox modern conceptions of 'body' and 'house'. Bodies, spaces, objects, vision, and gender constellate differently as patterns of 'power relations' or 'master narratives' or powerful subconscious structures. Critics routinely excavate everyday institutions; they agitate the relationship between signifier (words and images) and signified (the things words and images represent). In contemporary discourse, the mean24 ings of 'house' have shifted and split.

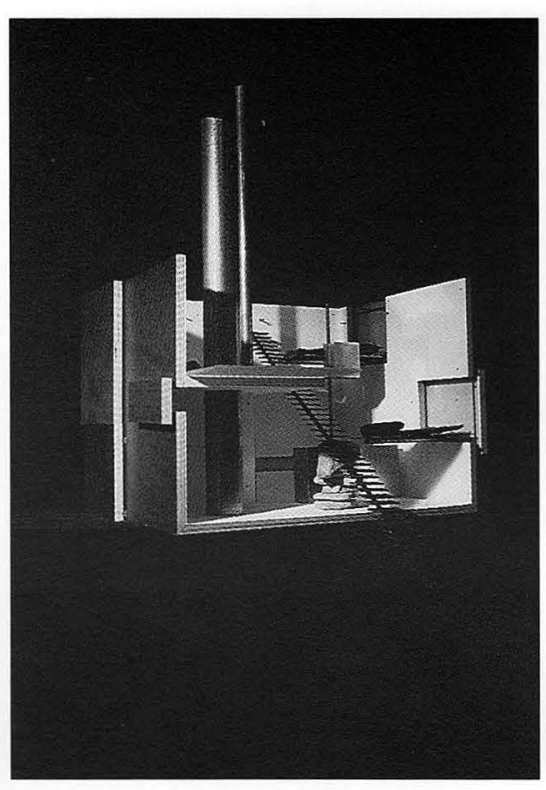

Dream House closed

puters, and telecommunication, consists of waking transactions between exterior and interior that begin to resemble the liquescent settings of the dream. In psychoanalytic schema, meaning occupies the tension between the visible and the concealed, which is also true of the house. Like other projects in the exhibition, Scogin Elam Bray's dream house opens to a surrealist landscape, where unlikely juxtapositions irritate domestic complacency. It extends the critical, visual practices of early twentieth century art, which explore the subconscious circulation of images in part as a response to the instability of value in the modern metropolis. Their dream house emerges in a robust, sometimes lyrical skepticism about the limits of form and physiognomy as domestic indicators. It exhibits a disciplined, material exuberance and a deeper, more philosophical ornamentality. This dream house seems to suggest that the refuge of the domestic is finally aesthetic, art housed in a darker laughter.

The dream dissolves limitation, gives full reign to desire. By "dream" we imply wish fulfillment or fantasy, also perfection, what we could have if we could have anything. A "dream" house, as distinct from a "real" house, is therefore always a construction that stands beyond rational,

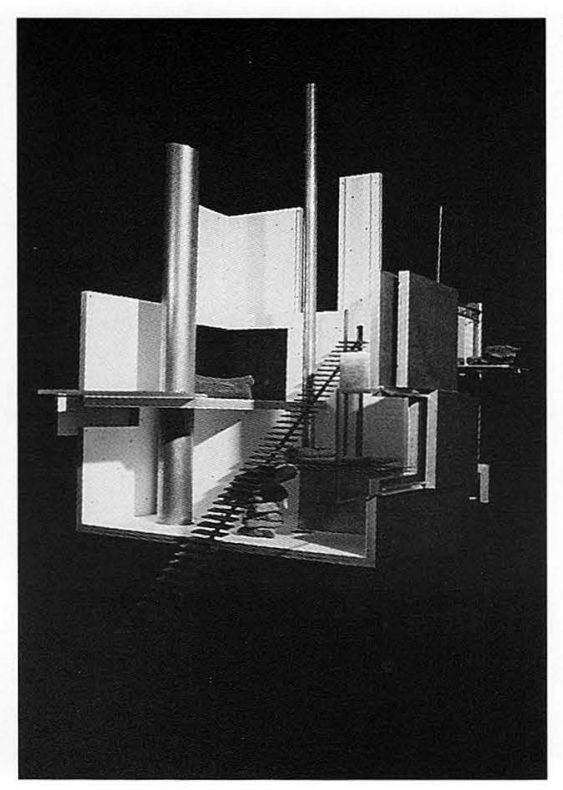

Dream House open

wakeful possibilities. Dream+house is a commercial figure of speech that plaits well-being with wealth; it sticks and sells because it situates the myth of security on the same horizon as limitless material gratification. Typically, this horizon prophesies a technologically advanced, life-lengthening 'future'. In its commonplace configuration, the dream-house therefore represents a goal based on a lack. Criteria for its mental or imaginary construction spring from a list of material objectives usually calculated in comparison to the 'best', 'most', or 'new', against which anything 'less' or 'old' suffers diminishing worth.

The dream of the commonplace dreamhouse is not a real dream. The typical dream-house of late capitalism is a daydream. It is a fabrication of the marketplace that belies real fabrication. A dreamhouse cannot withstand the accumulating imperfections of the real. Real buildings crack, leak, and stain. Commercial daydreams cannot abide the blemishing effects of weather and time, which also describe certain bodily characteristics. Modern commercial culture circumscribe the abject and taboo. Yet these are features that emerge to haunt the house of real dreams. Walls built by the unconscious have a mind of their own. 


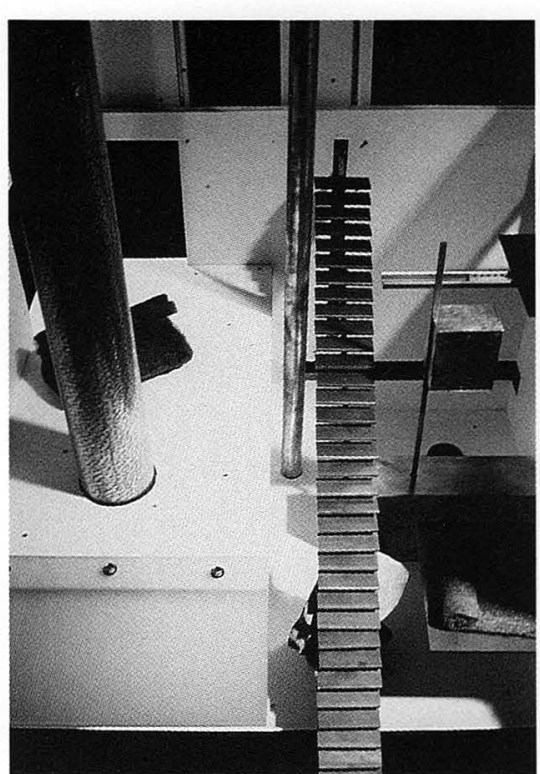

Dream House from sky

Even in the abstract, hallucinatory realm of the dream, the image and the allegory of the house belong to our oldest expressions of dwelling. In modern usage, "domestic" means "within the household"secure, safe, benign, tame, helpful. It also means controllable, not threateningnot natural, but human, or natural-tohumans. The first, dim, prehistoric domestication of wild surroundings appears as a kind of cutting away or clearing. Clearing and destroying predicate the first settlement. In his essay "House," Nadir Lahiji reminds us that each 'house', however new, is erected atop this primordial site of human becoming. ${ }^{1}$ The "house" of the West propagates its claim of belonging by attempting to domesticate everything. Domesticity is therefore one form of violence used to dominate an-other. 'Family' and 'civilization' are constructed out of an ancient dreaming. Newspaper headlines confirm over and over again that 'home', understood as an accumulation of ground, place, kinship, safety, and memory is our most volatile institution.

If, as Heidegger suggests, we dwell not in space but in language, contemporary thinking on the question of the domestic has undertaken a dismantling or disarticulation of this ontological house.

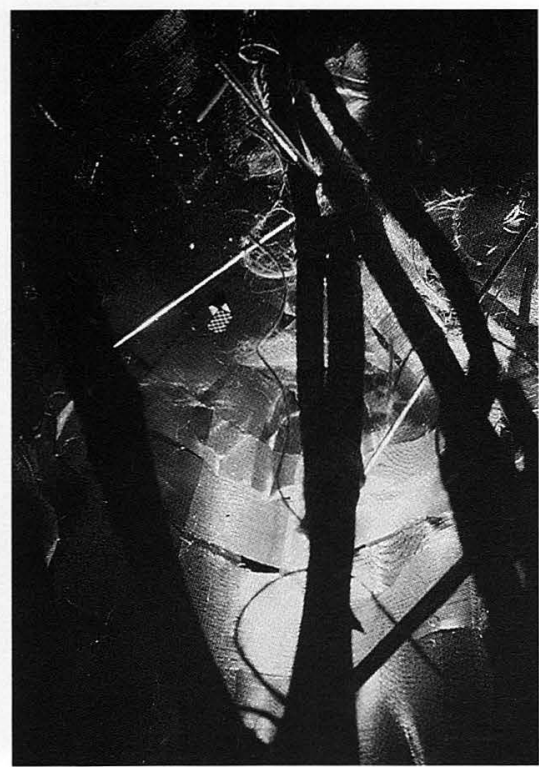

Dream House from earth

Thinking that underlies contemporary architecture is likewise radically reordered; ante- millennial architecture wants to overturn the unity of the relation between part and whole. Much of contemporary architectural design and criticism reconsiders the concept of building in relation to the bits and pieces of an anatomy mapped according to the literary, mythological, and psychoanalytic contour, not proportion or physiology. Indeed, the dream house suggests that our 'house' - dwelling itself-is coming undone at the seams. Such a disarticulation does not seek to escape the question of the whole. The whole from which it proceeds is neither a past nor a future construction; it is a taking apart that rehearses future reenactments of the dream of lost completeness.

On the face of it, then, domestic clearing embodies certain oppositions: inside and outside, security and danger, 'we' and 'they' self and other, the familiar and foreign. What Anthony Vidler calls the "modern unhomely" collects in the fractures and fissures that appear as a result of the tension between these opposites. When the boundaries that keep apart these opposites weaken and dissolve, dream-house turns into haunted house. In contrast to the house of the daydream,

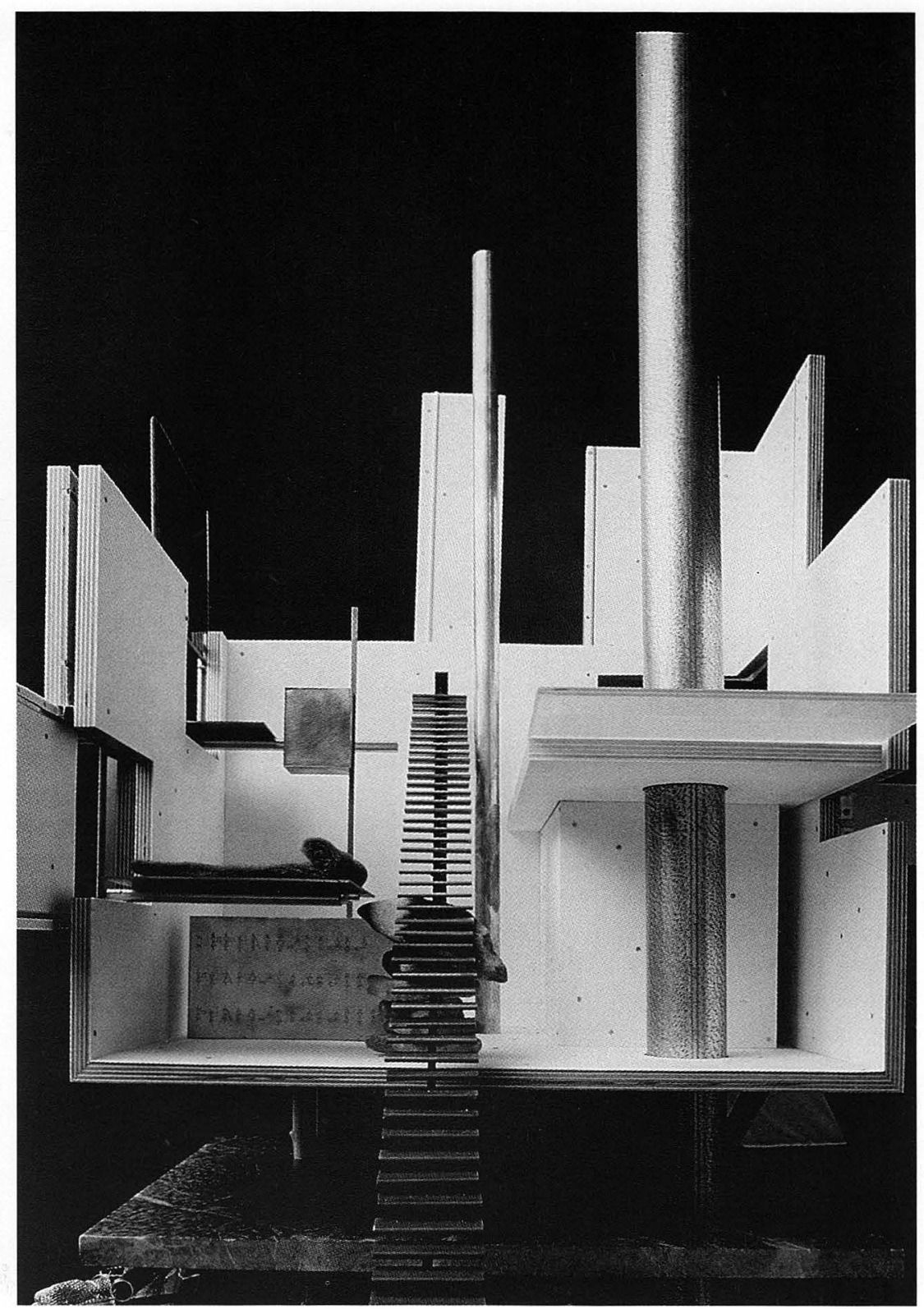

Domus Linea Insecare inside

which suggests freedom from outside intrusion, the house of the nightmare is infested with unsettling appearances. Unwelcome, otherworldly entities invade the interior and threaten to possess it. Rules of logic and science are powerless to defend it. On the one hand, the appearance of the dopplegangers and poltergeists signify a failure of domestic space; no matter how thick or familiar the walls or how strong the locks, ghosts get in. On the other hand, ghosts are inside to begin with; they constitute domestic space. All houses, however ordinary, are haunted, as Mark Wigley says. All houses have some wildness, some violence, some restless homelessness residing in the hollows of the wall. Wise and magical are the architects who call upon the guardian angels to hold this wildness at bay.

\section{Notes}

1. Nadir Z. Lahiij, "House," The Architects Dream (Cincinnati, Contemporary Arts Center, 1993), pp.56-61 The curators of the exbibit invited Mr. Labiji to contribute this theoretical essay as a project 